\title{
The Influence of the Number of Board of Commissioners, Company Size, Risk Monitoring Committee, and Financial Performance on Earnings Management
}

\author{
Hermanto ${ }^{1}$, Ratna Sari Natalia Berutu ${ }^{2^{\star}}$ \\ ${ }^{1,2}$ Faculty of Economics and Business, Esa Unggul University, Indonesia \\ Email: nataliabrutu2123@gmail.com
}

\begin{abstract}
The purpose of this study is to find determinants of profit management (Earnings Management) such as the number of board of commissioners, the size of the company, the risk monitoring committee, and the financial performance of a company. The current study uses banking sector financial statement data recorded at Bank Indonesia (BI) with selective sampling methods that meet survey criteria. Researchers examined a period of five years using a sample of 120 data from 24 banking sector entities. The study used several methods of linear analysis with secondary data types. This study shows that the size of the board of commissioners, the size of the company, and the risk monitoring committee, and the ROA jointly affect profit management. The size of the board of commissioners and the size of the company individually do not indicate any influence on profit management. Individual risk monitoring committees affect profit management and ROAs individually have a positive influence on profit management.
\end{abstract}

Keywords: Board of Commissioners, Company Size, Risk Monitoring Committee, Financial Performance, Earnings Management and Banking Sector Companies.

\section{A. INTRODUCTION}

Based on information from the Financial Services Authority (Financial Services Authority) in March 2020, the domestic economy experienced a slowdown, causing bank lending to decline. In the first quarter of 2020, the domestic economy was $2.97 \%$ (yoy), down from $4.97 \%$ (yoy) in the previous quarter (Financial Services Authority, 2020). The issue of unhealthy bank performance conditions will cause people to withdraw funds from banks which can reduce the bank's condition (Maulidia \& Wulandari, 2021; Nabila \& Daljono, 2013). Banks as intermediary institutions play a very important role in the economy of a country in collecting and distributing public funds so that they can strengthen the economic structure and stabilize the business cycle (Simatupang, 2019; Lukman, 2021). Financial statements are a source of information about whether or not a company is healthy, so companies tend to have stable financial performance that can provide benefits for investors. This indicates that the company is managing its financial performance well so that investors will invest their capital (Leon, 2020; Lukman, 2019).

Profits in the company are a reflection of the company's financial performance so that managers often manage earnings in achieving targeted revenues (Pramitha, 2021). Earnings management is carried out through discretionary accrual items including advertising costs, depreciation costs, and determination of uncollectible 
debt costs (Pramitha, 2021; Lukman, 2020). Earnings management practices in financial statements are used as a means to connect company managers with interested parties from outside the company, and can reduce the credibility of the financial statements themselves, because earnings management practices include manipulations that can mislead the interpretation of economic performance by stakeholders which results in errors. decision making (Subadriyah et al., 2020). Bank Bukopin reduced its net profit in 2016 by IDR. 183.56 billion which in the previous year was IDR. 1.08 T. By reducing profits so far, Bank Bukopin is considered to have carried out earnings management (Abidah et al., 2020).

The Board of Commissioners supervises managers in increasing profits in the company by conducting strategic direction which is part of the company's goals (Afnan \& Rahardja, 2015). The large number of commissioners will expand the scope of supervision which can reduce the potential for earnings management (Pramitha, 2021; Hermanto, 2018). Regulations issued by the Financial Services Authority in 2016, banks are required to have a minimum of three members of the board of commissioners and a maximum of the same as the number of members of the board of directors (Financial Services Authority, 2016; Indrati et al.,2021). In 2018, PT Bank Amar Indonesia had two members of the board of commissioners. Non-compliance with Financial Services Authority regulations has a negative impact on the bank's risk rating (Amar, 2018). Bank Amar Indonesia's ROA in 2018 decreased from 1.59\% to $0.79 \%$ while net profit for the year increased rapidly by $321 \%$ from IDR. 3.732 billion IDR. 16,291 billion (Amar, 2018).

Regulations issued by Financial Services Authority No 12/PFinancial Services Authority.03/2021, banks are grouped into 4 categories of KBMI (Bank Groups based on Core Capital). Banks with core capital below IDR.6 T are grouped into KBMI 1, banks with core capital above IDR.6 T to IDR. 14 T are grouped into KBMI 2, banks with core capital above IDR. $14 \mathrm{~T}$ to IDR.70 T are grouped into KBMI 3, and banks with core capital above IDR.70 T are grouped into KBMI 4 (Financial Services Authority, 2021). Companies that are classified as large or small are classified based on the size of their income, total assets, and total capital (Basyaib, 2007; Churchman, 2001). Companies that are able to optimize the performance of their assets so that they obtain large total assets are indicated as large companies (Hermanto, 2018; Purwanto, 2020). Reported to Kontan.co.id, Bank Mandiri contributed the largest asset of IDR. 1,117 trillion, an increase of $10.4 \%$ from the previous year (Sitanggang \& Handoyo, 2020; Hermanto, 2021). Large companies generally get attention from outside parties such as analysts, governments, and investors which causes companies to tend to avoid the very drastic ups and downs of profits by reporting stable earnings every year (Yatulhusna, 2015; Syahzuni, 2019).

The Risk Monitoring Committee is responsible to the commissioners by assisting them in the supervisory function regarding the implementation of risk management (Ekawati et al., 2017; Hermanto, 2017). The duties and authorities of the RMC (Risk Monitoring Committee) are to evaluate the company's risk management operations, give consideration to the risk management strategy, assess the 
company's financial reporting, and ensure that the company in practice is based on applicable law (Restuningdiah, 2011). Through regulations issued by Financial Services Authority No. 13/SEFinancial Services Authority.03/2017, the risk monitoring committee consists of a minimum of 3 people, one of which is an independent commissioner, and at the same time also serves as chairman, 1 expert in finance (accounting), and 1 expert in accounting. in the fields of law and banking (Financial Services Authority, 2017). In 2020, Bank OCBC has 8 risk monitoring committees of which 1 person holds concurrent position as chairman (independent commissioner), 2 people as members (independent party), 3 people as members, 1 person who is an expert in finance from an independent party and 1 person expert in risk management (OCBC, 2020).

The company's ability to generate profits can be determined by the Return On Asset (ROA) indicator (Sulistyoningsih \& Asyik, 2019). To increase the value of ROA, banks must obtain high net profits by channeling credit to the public (Dewi \& Purnawati, 2016; Putra, 2014; Rahayu et al., 2019). In semester I-2021, BCA posted a profit of IDR 14.45 trillion. Grow 18.10\% (yoy) while Permata bank posted IDR profit. 638 billion. Grow 74.32\% (yoy). BCA which won the largest net profit, including banks that recorded positive performance (Walfajri, 2021). The financial performance, which is assessed from the profit, becomes the attention of investors to find out the development of the company in the future. However, when the profit target is not achieved, the company's management takes advantage of the flexibility of accounting criteria when preparing financial statements by reshuffling profits which will later show good company performance (Sihombing \& Rano, 2020). Healthy financial performance can attract investors so that investors invest in the company (Alamudy, 2016).

Previous research found that the number of commissioners had a negative impact on the financial performance of Islamic banking with earnings management as a mediator. The more the number of the board of commissioners can slow down decision making so that it can reduce the company's performance. Good financial performance will reduce earnings management risk (Savitri et al., 2020; Subadriyah et al., 2020).

However, what the researcher examines is the population of conventional banks recorded at Bank Indonesia (BI) in the period 2016 to 2020. This study does not use intervening variables and makes earnings management a vocal variable that serves to find out how often earnings management practices in Indonesia are found in a company in the banking sector. Changing the size of the SSB (Size of the Sharia Supervisory Board) to the company size variable in order to find out whether company size can be an important indicator in earnings management practices. Changing the audit committee variable to a risk monitoring committee to find out how the risk monitoring committee plays a role in earnings management practices. The researcher also wants to know whether the management of the number of the board of commissioners, the size of the company, the number of risk monitoring committees and financial performance have an effect on the vocal variable of 
earnings management in the Indonesian banking sector. It is hoped that this study can provide a conceptual contribution to the development of the world economy and improve the financial performance of companies in the banking sector.

\section{B. LITERATURE REVIEW}

1. Relationship of the Board of Commissioners, Company Size, Risk Monitoring Committee, and Financial Performance to Earnings Management

Investors in making decisions related to investments in the form of shares usually look at the size of the company, where the size of the company tends to provide a lot of data or information. Management that is opportunistic tends to be more concerned with short-term profits so that investors tend to make wrong decisions. The implementation of good governance is expected to be one of the tools in providing confidence to investors about the return on funds invested in a company (Anggraeni \& Hadiprajitno, 2013). To increase the value of the company, management is required to do various things so that the condition of the company still looks good in the eyes of the public by displaying company profits as beautiful as possible. The risk monitoring committee evaluates and ensures compliance with applicable policies. The board of commissioners helps increase the effectiveness of its supervision of financial reports (Puspitowati \& Mulya, 2014). In previous research, company size negatively and significantly affects earnings management (Benazir, 2019). Earnings management also receives a negative influence from the risk monitoring committee (Ekawati et al., 2017). Earnings management receives a significant influence from the size of the board of commissioners (Anggraeni \& Hadiprajitno, 2013).

$\mathrm{H}_{1}$ : The number of commissioners, company size, risk monitoring committee, and ROA have an influence on earnings management

\section{Relationship of the Board of Commissioners to Earnings Management}

The purpose of the commissioner is to maximize the value of a company acting as the highest internal controller and responsible for monitoring the process of monitoring actions/decisions made by top management. Supervision by the board of commissioners is carried out to reduce the tendency of managers to carry out earnings management. Professional, open, efficient corporate governance and empowering functions as well as providing an independent attitude to corporate organs can help create transparency in earnings management in making financial reports (Paramitha, 2018). The results of previous studies stated that earnings management had a negative influence from the board of commissioners (Sumanto et al., 2014).

$\mathbf{H}_{2}$ : The number of commissioners negatively affects earnings management 


\section{Relationship of Firm Size to Earnings Management}

Company size affects the standard of funding in a company. The bigger the company, the greater the responsibility to meet the expectations of investors and shareholders. Large companies usually require more resources than small and medium-sized companies. Companies tend to avoid reporting losses (earnings losses) with a tendency to report profits to the company (Handayani \& Rachadi, 2009). In this case, large companies are more likely to manage their earnings by showing stable profits every year (Benazir, 2019). Previous research explained that company size negatively and significantly affects earnings management (Wardani \& Santi, 2018).

$\mathbf{H}_{3}$ : Firm size negatively affects earnings management

\section{Relationship of the Risk Monitoring Committee to Earnings Management}

The management of a company's governance is formed through the presence of the RMC (Risk Monitoring Committee) in the company because the presence of the RMC will disclose information about risk and risk management and supervision within a company. Income smoothing is a part of earnings management. RMC supports commissioners in fulfilling their responsibilities for risk oversight and internal control management. The implementation of internal governance, one of which is the risk monitoring committee, is expected to overcome agency theory constraints related to income distribution (Restuningdiah, 2011).

$\mathbf{H}_{4}$ : The risk monitoring committee has a negative influence on earnings management

\section{ROA Relationship to Earnings Management}

Accounting information helps investors and creditors make decisions based on the company's valuation. If the information is not valid, investors can make wrong decisions. Financial statements that can be made through earnings management can confuse financial statement users who think that the profit made is a valid number (Setiawati \& Na'im, 2000). The company manages its performance by increasing or decreasing profits from its financial statements. The high profit in the company indicates the maximum company performance so as to encourage investors to invest in the company (Apridasari, 2020). Based on the company's profit, investors can evaluate the good or bad performance of the company (Fortunate, 2018). Previous research has shown that ROA has a positive effect on earnings management (Amertha, 2013).



\section{METHOD}

This study uses data normality test, multicollinearity test, autocorrelation test, heteroscedasticity test, simultaneous test ( $\mathrm{f}$ test), partial test ( $\mathrm{t}$ test), and adjusted R2 test. Data processing using the SPSS application through purposive sampling technique in the banking sector recorded at Bank Indonesia (BI) from 2016 to 2020. 
The sample selection criteria used to select data in the study are the banking sector consistently recorded at Bank Indonesia (BI). until 2020, banking sector companies that do not always issue annual reports for the 2016-2020 research period, banking sector companies that do not consistently record profits during the 2016-2020 research period, and banking sector companies that have not IPO during the 20162020 research period.

This study obtained secondary data in the form of annual financial statements taken from the Indonesia Stock Exchange (IDX) website and the official website of each company in the banking sector. From 2016 to 2020 (with 5 years of observation), 24 banks were selected as a random sample from a total population of 55 banks. The time of this research starts from September 16, 2021 until February 28, 2022.

\section{RESULT AND DISCUSSION}

The following is a description of the results of statistical data processing in table 1 below:

Table 1. Descriptive Test

Descriptive Statistics

\begin{tabular}{|l|r|r|r|r|r|}
\hline & \multicolumn{1}{|c|}{ N } & \multicolumn{1}{c|}{ Minimum } & \multicolumn{1}{c|}{ Maximum } & \multicolumn{1}{c|}{ Mean } & Std. Deviation \\
\hline BOC & 120 & 67.00 & 333.00 & 178.0667 & 72.41149 \\
SIZE & 120 & 2359089.00 & 1511804628 & 248313788.1 & 376945551.4 \\
RMC & 120 & 3.00 & 10.00 & 4.7167 & 1.69618 \\
ROA & 120 & .07 & 4.00 & 1.7675 & 1.02893 \\
DA & 120 & -1011.74 & 2788.20 & 1.7551 & 285.09696 \\
Valid N (listwise) & 120 & & & & \\
\hline
\end{tabular}

Descriptive Statistics Test, from table 1 the number of data $(\mathrm{N})$ consists of 120 data. Through the test results above, the variable board of commissioners (BOC) has the smallest value of $67 \%$, the highest value of $333 \%$ with a mean of $178.0667 \%$ and the value of std. $72.41149 \%$ deviation. The minimum value for the variable company size (SIZE) is 2,359,089 million while the maximum value is $1,511,804,628$ million, with a mean of $248,313,788.1$ million and the value of std. deviation $376,945,551,4$ million. For the risk monitoring committee (RMC) variable, the smallest is $3 \%$, while the highest value is $10 \%$, with a mean of $4.7083 \%$, and the std value. deviation $1.68231 \%$. The ROA variable consists of a minimum value of $0.07 \%$, a maximum value of $4 \%$, an average value of $1.7675 \%$, and a standard deviation of $1.02893 \%$. Then for the dependent variable, namely earnings management (EM) has a minimum value of $-1011.74 \%$, a maximum value of $2788.20 \%$, and an average value of $1.7551 \%$, and a standard deviation of 285.09696

Normality test, Kolmogorov Smirnov test in this study shows that the data has a significant value of 0.881 where the value is above 0.05 . Through these results, it can be said that the data is normally distributed.

Autocorrelation test, this study uses the run test test as shown in table 4.3 which gets the asymp sig value. (2-tailed) of 0.086 . The results of the autocorrelation test showed a value above 0.05 . In this case, the data is free from autocorrelation. 
Multicollinearity test, each variable shows tolerance results per variable above 0.10 and each Variance Inflation Factor (VIF) value per variable below 10. Therefore, the data results are normally distributed.

Heteroscedasticity test, the results of the image in the form of dots that spread and do not form a certain pattern on the graph so that the data in this study is in accordance with the provisions of the Scatterplot method. Based on these provisions, this test is free from heteroscedasticity symptoms.

Simultaneous test ( $f$ test), based on the results of the regression obtained a significance result of 0.002 . Based on the significance value, a value below 0.05 indicates that there is a simultaneous effect. The results of the value can be concluded that the board of commissioners, company size, risk monitoring committee and ROA simultaneously affect earnings management.

Partial Test ( $t$ Test), the results of the t-test are presented in the following table:

Table 2. Partial Test (t Test)

\begin{tabular}{|lcc|l|}
\hline \multicolumn{1}{|c}{ Partial Test } & Betta & Significance & \multicolumn{1}{c|}{ Result } \\
\hline BOC $\rightarrow$ BC & 0.033 & 0.946 & Rejected \\
SIZE $\rightarrow$ BC & -0.218 & 0.094 & Rejected \\
RMC $\rightarrow$ BC & -1.352 & 0.018 & Accepted \\
ROA $\rightarrow$ BC & 0.288 & 0.042 & Accepted \\
\hline
\end{tabular}

Source: data proceed

Table 2 above, there is a partial effect of the independent variable with the dependent variable with a significance result below 0.05. In the table, the risk monitoring committee variable has a significant value of 0.018 and ROA has a significant value of 0.042 having an individual effect on earnings management, while the number of commissioners has a significant value of 0.946 and firm size has a significant value of 0.094 with no individual effect on earnings management.

Adjusted $\mathbf{R}^{2}$ test, a value close to 1 indicates that the independent variable will have a strong effect on explaining the dependent variable. It can be seen that the resulting value is 0.242 , indicating the number of commissioners, company size, risk monitoring committee and ROA providing an explanation of earnings management of $24.2 \%$.

Multiple Linear Regression, analysis is seen from the calculation of the statistical software used, thus obtaining the following equation:

$$
4,341 \mathrm{BC}=3,967+0,033_{\text {BOC }}-0,218_{\text {SIZE }}-1,352_{\text {RMC }}+0,288_{\text {ROA }}+1,623 \mathrm{e}
$$

The regression equation shows that the constant is 3.967. The coefficient on the number of commissioners increased by 0.033 if the number of commissioners changed by $1 \%$ earnings management would increase by 0.033 . The coefficient of company size decreased by 0.218 if the size of the company changed $1 \%$ earnings management increased by 0.218 . The coefficient of the risk monitoring committee decreases by 1.352 if the risk monitoring committee changes by $1 \%$ it will increase 
earnings management by 1.352 . Then the ROA coefficient increases by 0.288 if the ROA changes $1 \%$ it will increase earnings management by 0.288 .

\section{The Influence of the Number of Board of Commissioners, Company Size, Risk Monitoring Committee and ROA on Earnings Management}

Based on the results of the $\mathrm{f}$ test, the results describe the number of commissioners, company size, risk monitoring committees and ROA simultaneously affecting earnings management in the banking sector recorded at Bank Indonesia (BI) in 2016 to 2020. This supports previous research which states the number of the board of commissioners, company size, risk monitoring committee, and ROA affect earnings management (Puspitowati \& Mulya, 2014; Benazir, 2019). In accordance with the agency theory, which explains that the difference in interests between the agent and the principal causes management to have the motivation to increase the utility of the company. Earnings management is one of the actions of managers in achieving good performance. As a result, the financial statements do not provide a true reflection of the information, thus misleading stakeholders in making decisions based on the financial statements.

\section{Influence of the Board of Commissioners on Earnings Management}

Through the results of the $t$ test, it is stated that the size of the board of commissioners does not significantly affect earnings management in the banking sector recorded at Bank Indonesia (BI) from 2016 to 2020 so that this finding contradicts the findings (Sumanto et al., 2014) which describes the size of the the board of commissioners has a negative and significant effect on earnings management. The current study is in contrast to (Paramitha, 2018) which shows that the size of the individual board of commissioners has no effect on earnings management. The board of commissioners is not the only indicator that ensures effective oversight of the company. As for other factors such as: coordination, communication and decision-making factors.

\section{Effect of Firm Size on Earnings Management}

Through the results of the $t$ test, it shows that the size of the company does not significantly affect earnings management in the banking sector recorded at Bank Indonesia (BI). This study contradicts findings (Wardani \& Santi, 2018) which explain that firm size has a negative effect on earnings management. This study agrees with (A. Y. Astuti et al., 2017) which explains that individual (partial) firm size does not affect earnings management. When the number of company assets is getting bigger, the company will get large capital from investors so that the debt turnover is also getting bigger. Large companies have many assets that allow assets not to be managed properly. Therefore, earnings management practices are more caused by errors in disclosing total assets. 


\section{Influence of the Risk Monitoring Committee on Earnings Management}

Through the results of the $t$ test, the results show that the risk monitoring committee significantly affects earnings management in the banking sector recorded at Bank Indonesia (BI) and contradicts research (Ekawati et al., 2017) which shows a negative impact on RMC and does not significantly affect earnings management. The increase in the size of the risk monitoring committee is a form of high supervision of manager behavior. The larger the size of the risk monitoring committee, the more resources the company needs to solve problems. In this case, the increasing size of the committee can suppress earnings management practices.

\section{Effect of ROA on Earnings Management}

Through the t-test, the results show that ROA affects earnings management positively and significantly in the banking sector recorded at Bank Indonesia from 2016 to 2020 and agrees with the research (Amertha, 2013). A high ROA value is an indicator for investors to invest in a company. In addition to the motivation to attract investors, ROA that affects earnings management is in line with agency theory which states that there is an interest in the relationship between managers (agents) and shareholders where sometimes management takes actions that benefit personal interests. A positive ROA aims to achieve a stable level of ROA by practicing earnings management, either by minimizing or maximizing company profits.

\section{E. CONCLUSION}

From the discussion of the previous results, it was found that the number of commissioners, company size, risk monitoring committee and ROA simultaneously affect earnings management. The board of commissioners that have a positive impact does not show a significant effect on earnings management. The size of the company that has a negative impact does not show a significant effect on earnings management. Meanwhile, the risk monitoring committee has a negative and significant influence on earnings management. Then ROA also affects earnings management with a positive and significant impact.

The limitation of this research is that the only indicator to assess financial performance is only using ROA proxy, which does not adequately reflect the state of a company's financial performance. Therefore, it is hoped that further research will add other indicators to assess financial performance specifically in the banking sector. Another limitation is that the earnings management perspective in this study is based on opportunistic dimensions. For further studies, it is hoped that earnings management can be viewed from other dimensions, such as efficiency.

\section{REFERENCES}

1. Abidah, N., Nugroho, T. R., \& Ilmiddavid, M. B. (2020). Pengaruh Manajemen Laba pada Return Saham dengan Kualitas Audit dan Kepemilikan Manajerial sebagai Variabel Pemoderasi (Studi Empiris pada Perusahaan .... 1-14.

2. Afnan, A., \& Rahardja. (2015). Pengaruh Ukuran Dewan Komisaris dan Proporsi 
Komisaris Independen terhadap Kinerja Keuangan dengan Manajemen Laba Sebagai Variabel Intervening. Diponegoro Journal of Accounting, Vol. 4 No.), 1-14.

3. Alamudy, H. O. (2016). Pengaruh Manajemen Laba Terhadap Kinerja Keuangan Perusahaan (Studi Pada Perusahaan Manufaktur di BEI Periode 2011-2012). Jurnal Akuntansi, 1-17.

4. Amertha, I. S. P. (2013). Pengaruh Return On Asset pada Praktik Manajemen Laba dengan Moderasi Corporate Governance. 2, 373-387.

5. Anggraeni, R. M., \& Hadiprajitno, P. B. (2013). Pengaruh Struktur Kepemilikan Manajerial, Ukuran Perusahaan, Dan Praktik Corporate Governance Terhadap Manajemen Laba. None, 2(3), 754-766.

6. Apridasari, E. (2020). Analisis Manajemen Laba Bank Konvensional dan Bank Syariah di Bursa Efek Indonesia. 3, 93-102.

7. Arif, L., \& Karmila, K. (2019). Pengaruh Pemberian Pupuk Organik Kompos Kandang Sapi Terhadap Pertumbuhan Dan Hasil Tanaman Cabe Keriting (Capsicum annum L). Jurnal Agrotech, 9(1), 7-11.

8. Astuti, A. Y., Nuraina, E., \& Wijaya, A. L. (2017). Pengaruh Ukuran Perusahaan Dan Leverage Terhadap Manajemen Laba. The 9th FIPA: Forum Ilmiah Pendidikan Akuntansi - Universitas PGRI Madiun, 5(1), 399-417.

9. Astuti, R. P. (2015). Pengaruh Profitabilitas , Size , Growth Opportunity , Likuiditas Dan Struktur Aktiva Terhadap Strukur Modal Bank. Jurnal Akuntansi, 1(1), 1-19.

10. Basyaib. (2007). Manajemen Resiko - Google Buku.

11. Benazir. (2019). Pengaruh Profitabilitas, Leverage dan Ukuran Perusahaan terhadap Manajemen Laba. Skripsi.

12. Bertuah, E. (2018). Determinan Informasi Kinerja Keuangan terhadap Return Saham Perusahaan Manufaktur. 15.

13. Cadbury Committee. (1992). Report of the Committee on the Financial aSpects of Corporate Governance.

14. Churchman, C. W. (2001). Value of the Firm: Who Gets the Goodies. 1952, 1-24.

15. Dewi, I., \& Purnawati, N. (2016). Analisis Kinerja Keuangan Perbankan Sebelum Dan Sesudah Akuisisi Pada Bank Sinar Bali. E-Jurnal Manajemen Universitas Udayana, 5(6), 253573.

16. Ekawati, D. R., Nugroho, Ridho, T., \& Rubiyanto. (2017). Pengaruh Karakteristik Dewan Komisaris Independen, Komite Audit, dan Risk Management Committee terhadap Manajemen Laba. 1-12. http://repository.unim.ac.id/1700/

17. Handayani, R. S., \& Rachadi, A. D. (2009). Pengaruh Ukuran Perusahaan terhadap Manajemen Laba. Progress of Theoretical Physics, 105(4), 537-571.

18. Hermanto, H. (2017). Perilaku Mahasiswa Ekonomi di Universitas Esa Unggul dalam Melakukan Investasi di Pasar Modal. Jurnal Ekonomi Universitas Esa Unggul, 8(01), 79445.

19. Hermanto, H. (2018). Analisis Pembagian Deviden Pada Perusahaan Yang Tercatat di BEI. Jurnal Akuntansi Bisnis, 11(1).

20. Hermanto, H. (2021). Model Triple Bottom Menuju Kinerja Keuangan. Jurnal 
Akuntansi dan Bisnis: Jurnal Program Studi Akuntansi, 7(2), 166-179.

21. Hermanto, H., \& Tjahjadi, E. (2021). Analisis Rasio Profitabilitas, Solvabilitas Terhadap Stock Price Perusahaan Perbankan. Jurnal Ilmiah MEA (Manajemen, Ekonomi, E Akuntansi), 5(1), 1579-1595.

22. Hermanto, H. (2018). Pengaruh Profitabilitas, Ukuran Perusahaan dan Kepemilikan Saham Publik Terhadap Return Saham dengan CSR Sebagai Variabel Intervening. Jurnal Ekonomi.

23. Indrati, M., Hermanto, H., Purwaningsih, E., Agustinah, W., \& Sarikha, A. (2021). Corporate Governance Mechanisms and Possible Financial Statements Containing Fraud. Budapest International Research and Critics Institute (BIRCIJournal): Humanities and Social Sciences, 4(4), 8609-8621.

24. Jensen, M., \& Meckling, W. (1976). Theory of the firm: Managerial behavior, agency costs, and ownership structure. The Economic Nature of the Firm: A Reader, Third Edition, 283-303. https://doi.org/10.1017/CBO9780511817410.023

25. Leon, F. M. (2020). Pengaruh Intellectual Capital terhadap Kinerja Keuangan Perusahaan Perusahaan Go Publik di Indonesia. Kompartemen: Jurnal Ilmiah Akuntansi, 17(1). https://doi.org/10.30595/kompartemen.v17i1.3971

26. Lukman. (2021). The Utilization of Organic Waste Chicken Cage Fertilizer on the Growth of Cocoa (Theobroma Cacao L.). International Journal of Science and Society, 3(4), 167-176.

27. Lukman. (2020). The Influence of Guano Organic Fertilizer in Sustainable Agricultural Systems on Growth and Results of Sweet Corn Plants (Zea mays saccharata L). ENDLESS : International Journal of Future Studies, 3(2), 128-138.

28. Lukman. (2021). Kombinasi Penggunaan Kompos Eceng Gondok (Eichhornia Crassipes) Dengan Pupuk Kandang Ayam Terhadap Laju Pertumbuhan Bibit Tanaman Kopi Robusta (Coffea canephora). Jurnal Sains dan Teknologi, 10(2), 200-2010

29. Maizal Walfajri. (2021). Di antara bank-bank besar, BCA raih laba bersih paling jumbo di semester I-2021. 2021. https://newssetup.kontan.co.id/news/di-antarabank-bank-besar-bca-raih-laba-bersih-paling-jumbo-di-semester-i-2021

30. Maulidia, N., \& Wulandari, P. P. (2021). Analisis Kinerja Keuangan Bank di Masa Pandemi Covid-19 Bank BUMN yang Terdaftar di Bursa Efek Indonesia. 11.

31. Medyawati, H., \& Dayanti, A. S. (2016). Pengaruh Ukuran Perusahaan Terhadap Manajemen Laba: Analisis Data Panel. Jurnal Ilmiah Ekonomi Bisnis, 21(3), 96409. https://doi.org/10.35760/eb.

32. Nabila, A., \& Daljono. (2012). Pengaruh Proporsi Dewan Komisaris Independen, Komite Audit, dan Reputasi Auditor terhadap Manajamen Laba. DIPONEGORO JOURNAL OF ACCOUNTING, 2(1), 1-10. http://ejournals1.undip.ac.id/index.php/accounting

33. Nabila, A., \& Daljono. (2013). Pengaruh Proporsi Dewan Komisaris Independen, Komite Audit, dan Reputasi Auditor terhadap Manajemen Laba. 2(1997), 1-10.

34. Paramitha, O. A. (2018). Analisis Pengaruh Profitabilitas, Ukuran Perusahaan dan Ukuran Dewan Komisaris terhadap Manajemen Laba pada Perusahaan 
Manufaktur yang Terdaftar di Bursa Efek Indonesia. Indonesia Banking School, April, 5-24.

35. Pramitha, A. N. (2021). Pengaruh Struktur Kepemilikan, Ukuran Komite Audit, Ukuran Dewan Komisaris dan Jenis Kepemilikan Terhadap Manajemen Laba. Jurnal Akuntansi Bisnis, 19(2), 142. https://doi.org/10.24167/jab.v19i2.3663

36. Purwantoro, Y. (2020). Pengaruh Kinerja Keuangan terhadap Nilai Perusahaan dengan Good Corporate Governance sebagai Variabel Moderasi pada Perusahaan Pertambangan.

37. Puspitowati, N. I., \& Mulya, A. A. (2014). Pengaruh Ukuran Komite Audit, Ukuran Dewan Komisaris, Kepemilikan Manajerial, dan Kepemilikan Institusional terhadap Kualitas Laba. 3(1).

38. Putra, A. (2014). Penerapan 5 Pilar Tata Kelola Terhadap Nilai Perusahaan Perbankan di Indonesia. Journal Fakultas Ekonomi Universitas Indonusa Esa Unggul, 11(1), 149-164.

39. Rahayu, N. E., Izatunnafsi, I., \& Sugiyanto, S. (2019). Pengaruh Faktor Risk Profiles, Good Corporate Governance, Earning, Capital dan Jenis Bank terhadap Kinerja Keuangan Bank Umum. Jurnal Ekonomi : Journal of Economic, 9(02).

40. Rahmawati, I. A., Rikumahu, B., \& Dillak, V. J. (2017). Pengaruh Dewan Direksi, Dewan Komisaris, Komite Audit dan Corporate Social Responsibility Terhadap Kinerja Keuangan Perusahaan. Jurnal Akuntansi Dan Ekonomi, 2(2), 54-70.

41. Restuningdiah, N. (2011). Komisaris Independen, Komite Audit, Internal Audit dan Risk Management Committee Terhadap Manajemen Laba. 15(3), 351-362.

42. Savitri, E., Andreas, A., Syahza, A., Gumanti, T. A., \& Abdullah, N. H. N. (2020). Corporate governance mechanism and financial performance: Role of earnings management. Entrepreneurship and Sustainability Issues, 7(4), 3395-3409.

43. Schipper, K. (1989). Schipper 1989.pdf (p. 91).

44. Setiawati, L., \& Na'im, A. (2000). Manajemen Laba. 15(4), 424-441.

45. Sihombing, T., \& Rano, K. B. S. (2020). Analisis Kinerja Keuangan Terhadap Manajemen Laba Pada Perusahaan Sektor Industri Dasar dan Kimia Yang Terdaftar di Bursa Efek Indonesia Periode 2016-2018. Jurakunman (Jurnal Akuntansi dan Manajemen), 13(2). https://doi.org/10.48042/jurakunman.v13i2.54

46. Simatupang, H. B. (2019). Peranan perbankan dalam meningkatkan perekonomian indonesia. Jurnal Riset Akuntansi Multiparadigma, 6(2), 136-146.

47. Sitanggang, L. M. S., \& Handoyo. (2020). Walau kredit tersendat, aset perbankan tetap tumbuh tinggi. https://keuangan.kontan.co.id/news/walau-kredit-tersendataset-perbankan-tetap-tumbuh-tinggi

48. Subadriyah, Sa'diyah, M., \& Murniati. (2020). Praktik manajemen laba: Sebuah kajian studi hermeneutika. 23(2), 225-242.

49. Sulistyoningsih, N., \& Asyik, N. F. (2019). Pengaruh Good Corporate Governance Dan Kinerja Keuangan Terhadap Manajemen Laba. Jurnal Ilmu Dan Riset Akuntansi, 8(3), 1-20.

50. Sumanto, B., Asrori, \& Kiswanto. (2014). Pengaruh Kepemilikan Institusional Dan Ukuran Dewan Komisaris Terhadap Manajemen Laba. Accounting Analysis 
Journal, 3(1), 44-52.

51. Syahzuni, B. A. (2019). Pengaruh Profitabilitas dan Risiko Keuangan terhadap Kualitas Laporan Keuangan Serta Nilai Perusahaan pada Perusahaan Food and Beverage yang terdapat di BEI.

52. Wardani, D. K., \& Santi, D. K. (2018). Pengaruh Tax Planning, Ukuran Perusahaan, Corporate Social Responsibility (Csr) Terhadap Manajemen Laba. Jurnal Akuntansi, 6(1), 11-24.

53. Yatulhusna, N. (2015). Pengaruh Profitabilitas, Leverage, Umur dan Ukuran Perusahaan terhadap manajemen laba. 23-undefined. 